\title{
On Being the Right Size as an Animal with Plastids
}

\author{
Cessa Rauch ${ }^{1}$, Peter Jahns ${ }^{2}$, Aloysius G. M. Tielens ${ }^{3,4}$, Sven B. Gould ${ }^{1 *}$ and \\ William F. Martin ${ }^{1}$
}

${ }^{1}$ Molecular Evolution, Heinrich-Heine-University, Düsseldorf, Germany, ${ }^{2}$ Plant Biochemistry, Heinrich-Heine-University, Düsseldorf, Germany, ${ }^{3}$ Department of Biochemistry and Cell Biology, Faculty of Veterinary Medicine, Utrecht University, Utrecht, Netherlands, ${ }^{4}$ Department of Medical Microbiology and Infectious Diseases, Erasmus University Medical Center, Rotterdam, Netherlands

Plastids typically reside in plant or algal cells - with one notable exception. There is one group of multicellular animals, sea slugs in the order Sacoglossa, members of which feed on siphonaceous algae. The slugs sequester the ingested plastids in the cytosol of cells in their digestive gland, giving the animals the color of leaves. In a few species of slugs, including members of the genus Elysia, the stolen plastids (kleptoplasts) can remain morphologically intact for weeks and months, surrounded by the animal cytosol, which is separated from the plastid stroma by only the inner and outer plastid membranes. The kleptoplasts of the Sacoglossa are the only case described so far in nature where plastids interface directly with the metazoan cytosol. That makes them interesting in their own right, but it has also led to the idea that it might someday be possible to engineer photosynthetic animals. Is that really possible? And if so, how big would the photosynthetic organs of such animals need to be? Here we provide two sets of calculations: one based on a best case scenario assuming that animals with kleptoplasts can be, on a per $\mathrm{cm}^{2}$ basis, as efficient at $\mathrm{CO}_{2}$ fixation as maize leaves, and one based on ${ }^{14} \mathrm{CO}_{2}$ fixation rates measured in plastid-bearing sea slugs. We also tabulate an overview of the literature going back to 1970 reporting direct measurements or indirect estimates of the $\mathrm{CO}_{2}$ fixing capabilities of Sacoglossan slugs with plastids.

Keywords: Elysia, Sacoglossa, photosynthetic slugs, photosynthetic animal, growth rate, life cycle

\section{INTRODUCTION}

This article was submitted to Plant Physiology, a section of the journal Frontiers in Plant Science

Received: 28 April 2017

Accepted: 27 July 2017 Published: 17 August 2017

Citation:

Rauch C, Jahns P, Tielens AGM, Gould SB and Martin WF (2017) On Being the Right Size as an Animal with

Plastids. Front. Plant Sci. 8:1402. doi: 10.3389/fp/s.2017.01402
The group of sea slugs belonging to the order Sacoglossa really know how to keep biologists busy. The group comprises about 400 species of small, soft-bodied marine animals (Figure 1A) that feed upon algae (Jensen, 2007; Wägele et al., 2011). The algal food is what mainly keeps the biologists busy. Adult sacoglossans feed upon not just any algae, but upon siphonaceous algae (Figure 1B). Siphonaceous describes large, tube-like filamentous algae, often having a reduced, hardly visible vacuole, meaning that they are filled with a rich cytosol, sometimes containing many hundreds of plastids. The sacoglossans possess a highly-specialized radula, a molluscan version of teeth (Figure 1A; zoom-in panel), that allows them to puncture their algal prey and suck out the cytoplasmic contents, which they then digest (Trench, 1969; Wägele et al., 2011).

A small number of sacoglossan species perform a very special trick: they do not digest the plastids, but they sequester them instead as kleptoplasts within the cells of their digestive gland (Rumpho et al., 2001; Händeler et al., 2009; de Vries et al., 2014a), giving the slugs their distinct 


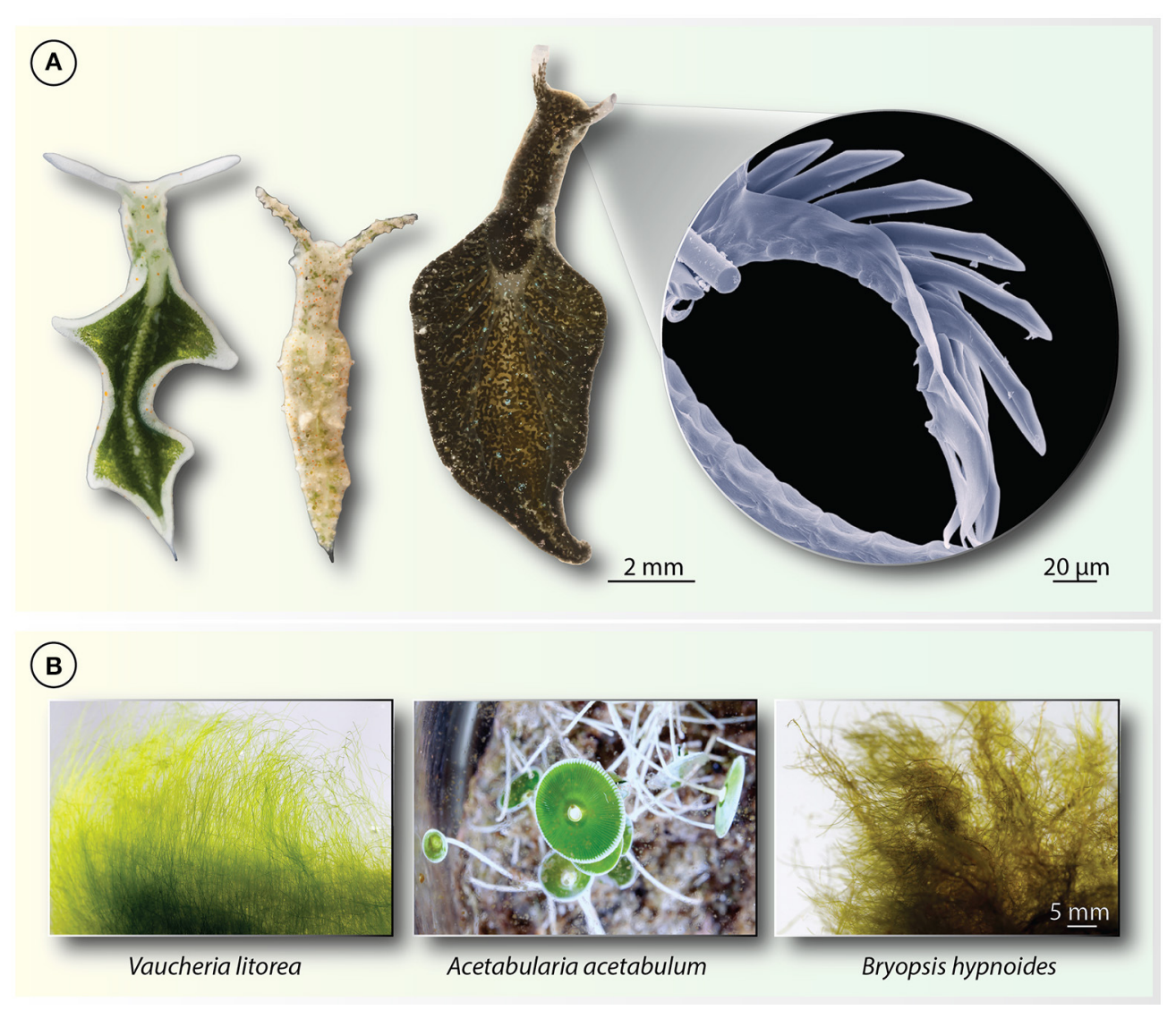

FIGURE 1 | Examples of sacoglossan sea slugs and their algal food. (A) From left to right the three Sacoglossa Elysia timida, Elysia cornigera, and Elysia viridis. All use a radula to penetrate siphonaceous algae from which they suck out the cytosolic content (hence the name sap sucking slugs) that includes compartments such as mitochondria, nuclei, and plastids. Plastids are specifically sequestered (the kleptoplasts) and incorporated into the cells that line the digestive tubules, in some cases giving the slugs their characteristic green color. The radula is a chitinous feeding structure of molluscs comparable teeth. A scanning-electron micrograph of one of $E$. viridis is shown on the very right, revealing the individual teeth-like structures the animals use to penetrate the algal cell wall. (B) Examples of macroalgae on which Sacoglossa feed and that are siphonacous. Some Sacoglossa are highly specialized and feed on single alga species, such as E. timida that only feeds on Acetabularia, while others such as E. viridis can feed on a larger variety of macroalgae.

green color. Electron microscopy experiments showed that the plastids can stay morphologically intact for days, weeks, or even months (Greene, 1970; Rumpho et al., 2001; Händeler et al., 2009). Early investigations in the 1970s indicated that the sequestered plastids remain photosynthetically active (Giles and Sarafis, 1972; Hinde and Smith, 1972; Trench and Ohlhorst, 1976). Accordingly, these sacoglossans have been described as "photosynthetic" for many decades. Indeed, the slugs could survive in the light for weeks without food, just with plastids (Pierce et al., 1996). More recent investigations, however, showed that the slugs with plastids survive in the dark, too, and that the presence of photosynthesis inhibitors also does not significantly, if at all, increase the rate with which they lose weight (Christa et al., 2014; de Vries et al., 2015). It seems that some sacoglossan species are simply more starvation tolerant than others and that has to do with better coping with reactive oxygen species (de Vries et al., 2015). Indeed, all slugs shrink during starvation and some can go from centimeters to millimeters in length when deprived of a food source. The green sacoglossans are no exception if starved (Mujer et al., 1996; Pelletreau et al., 2012; Klochkova et al., 2013; Christa et al., 2014; de Vries et al., 2015), that is, if they are forced to turn to autophagy for energy generation (de Vries et al., 2015). It thus appears that what we once thought were animals that are good at photosynthesis are first and foremost good at fasting. However, the concept of "photosynthetic animals" has considerable inertia in the literature. The media in particular regularly want to know about the status and future of photosynthetic animals.

Such discussions inevitably lead to debates of whether it might someday be possible to construct photosynthetic farm animals, given all that modern science can do with gene technology and the like. Thus, there is a need to critically inspect the concept of photosynthetic animals. The first and most obvious issue is that they would need a lot of surface area to harvest that light (Smith and Bernays, 1991). How much area would they need and, conversely, what portion of a green slug's food requirements can be covered from sequestered plastids? In the spirit of Haldane et al. (1926) essay "On being the right size," 
let us take a look, using some rough but robust and very conservative estimates.

\section{THE SIZE OF PHOTOSYNTHETIC ANIMALS}

If we go into the literature, we can readily find most of the values that we need. Fast growing dairy cows gain weight at a rate of about $1 \mathrm{~kg}$ per day, slow growing cows gain roughly $0.5 \mathrm{~kg}$ per day (Brody and Ragsdale, 1930). Let's use the $0.5 \mathrm{~kg}$ per day value, to which we will return later. Another value we need is how much food is required to generate that weight. An old rule of thumb is that roughly 5-6 kg of maize are needed to generate $1 \mathrm{~kg}$ of beef, though modern numbers provide a range of 3-10 kg of maize per $\mathrm{kg}$ of beef (Tilman et al., 2012). Cows consist of more than beef, though, so let's be generous and assume that only $3 \mathrm{~kg}$ of maize are needed per kg of cow bodyweight. In order to get our cow through one growing season, that is, through 1 year (and hence $180 \mathrm{~kg}$ of weight gain), $540 \mathrm{~kg}$ of maize would be required-let's grant another $10 \%$ in improved feed conversion efficiency and call it $500 \mathrm{~kg}$ of maize seed that is needed to grow our cow for a year. This is deliberately an underestimate, to be conservative.

How much leaf area is needed to produce those $500 \mathrm{~kg}$ of maize seed? Under excellent field conditions (good soil, good sunlight, sufficient water, and fertilizer) maize can yield about 160 bushels per acre (http://cropwatch.unl.edu/corn/yieldtrends), which converts to about 10 tons per hectare, or roughly $1 \mathrm{~kg} / \mathrm{m}^{2}$. Maize has a leaf area index of about 3 , meaning $3 \mathrm{~m}^{2}$ leaf area per $\mathrm{m}^{2}$ field area (Watson, 1947; Wilhelm et al., 2000), such that yield, expressed in units of leaf area, corresponds to roughly $0.3 \mathrm{~kg}$ of maize seed per square meter of maize leaf area. Since we need $500 \mathrm{~kg}$ of maize per season, that means that our cow would need about $1,600 \mathrm{~m}^{2}$ of surface area with the photosynthetic efficiency of maize (Tollenaar, 1983), one of the top-efficiency photosynthesizers known, to sustain that $0.5 \mathrm{~kg}$ per day growth rate, averaged over the year. Thus, under optimal field conditions and with the photosynthetic efficiency of maize, our photosynthetic cow needs a leaf roughly $40 \times 40 \mathrm{~m}$ in size, about a third the size of a football field. We note that unless our leafbearing cow has the phenotypic appearance of a maize plant, it is going to have a leaf area index very close to 1 , which is 3 -fold less efficient per square meter than maize, even if it has the same photosynthetic efficiency.

Of course, our estimate so far assumes that the biogenesis and maintenance of the photosynthetic organ itself consumes no photosynthates. Were the organ is on average $1 \mathrm{~cm}$ thick, it would weigh $10 \mathrm{~kg} / \mathrm{m}^{2}$, which corresponds to $16,000 \mathrm{~kg}$ total "leaf" weight because we need $1,600 \mathrm{~m}^{2}$ of photosynthetic surface area to generate $500 \mathrm{~kg}$ of maize seed to support $180 \mathrm{~kg}$ of weight gain per year (growing season). That is going to pose insurmountable problems, because the cow's "leaf" requires 88 times more body mass synthesis than the $180 \mathrm{~kg}$ of weight gain it is supposed to support. So let us assume that molecular biologists and gene engineers can find ways to make it $1 \mathrm{~mm}$ thick on average, adding only $1,600 \mathrm{~kg}$ of extra weight. That leaf will require 9 growing seasons to synthesize at a growth rate of $180 \mathrm{~kg}$ per year, and we have still not generated the $180 \mathrm{~kg}$ per year net surplus cow material for harvesting. Thirty months is a late "terminal age" for cattle (Bouton et al., 1978), meaning our photoengineered cow would have to spend three lifetimes growing its leaf before it gets started growing the body (at $180 \mathrm{~kg}$ per year). It is rapidly becoming clear that the photosynthetic cow project (a photobovid) is not going to work out very well, and we furthermore are beginning to understand more clearly why cows eat grass all day, leaving it to plants to do the heavy lifting of photosynthesis and leaving it to their anaerobic gut flora to break cellulose down into short chain fatty acids (acetate, propionate, and butyrate) that the cows can resorb as food (Bauchop and Mountfort, 1981; Dijkstra et al., 1993).

Let's be unrealistically generous, however, and say that our cow does not have to invest any photosynthates at all in the synthesis of its leaf-it gets the leaf for free. This would then be equivalent to the situation of the saccoglossan slugs, which grow up without photosynthesis and incorporate plastids into a ready-made leaf, their parapodia. If we generously gauge the shadow-generating surface area of the cow without the leaf as $2 \mathrm{~m}^{2}$, then the photosynthesizing animal needs to have an organ with 800 times its own photosynthetically effective surface area. Put another way, with its own surface, the animal could cover about $0.1 \%$ of its growth needs $(2 / 1,600)$, if it was, on a per $\mathrm{cm}^{2}$ basis, as photosynthetically efficient as maize.

We have also left another important limiting factor-water demands-out of the calculation. The situation at the water trough for those engineered farm animals opens up a whole new set of problems into which we do not delve here. That brings us back to the slugs. The slugs are different from the cows, of course. They are a lot smaller, they are not warm-blooded so they do not need to generate lost heat, and they have a different growth rate.

\section{THE PLASTID CONTRIBUTION TO PHYSIOLOGY IN SLUGS}

A well-studied slug species is Elysia timida (Figure 1A), which under good laboratory conditions can grow to a fresh weight of roughly $100 \mathrm{mg}$, corresponding to a dry weight of ca. $10 \mathrm{mg}$ per animal. In our own E. timida laboratory cultures and controlled conditions (Schmitt et al., 2014), the time from egg hatching to the juvenile stage is about 20 days. They start feeding on siphonaceous algae at day 3 after egg hatching (Schmitt et al., 2014). By day 20 they are $\sim 0.1 \mathrm{mg}$ in weight and $0.5 \mathrm{~mm}$ long. From that point, they require an additional 7-8 weeks to reach their final size with a dry weight of roughly $10 \mathrm{mg}$. In total, it takes about 12 weeks for E. timida to develop from eggs to maturity (Schmitt et al., 2014).

How much of that dry weight can come from photosynthesis in sequestered plastids? The average eukaryotic cell has a dry weight formula of roughly $\mathrm{C}_{5} \mathrm{H}_{7} \mathrm{O}_{2} \mathrm{~N}$, meaning that eukaryotes are roughly $50 \%$ carbon by dry weight (Heldal et al., 1985). A slug of ca. $10 \mathrm{mg}$ dry weight therefore contains $5 \mathrm{mg}$ of carbon (5 mg C). From Christa et al. (2014) we know that the experimentally determined $\mathrm{CO}_{2}$ incorporation rates for E. timida are $30 \mathrm{nmol}$ of $\mathrm{CO}_{2}$ in $2 \mathrm{~h}$ for four animals. This translates to $45 \mathrm{nmol} \mathrm{C}$ per animal per 12-h photosynthetic period, which converts to $540 \mathrm{ng}$ of carbon per animal per 12-h-daylight day. 
The adult animal contains $5 \mathrm{mg} \mathrm{C}$; photosynthesis in fully grown animals can provide $0.54 \mu \mathrm{g}$ per day, which corresponds to $0.011 \%$ incorporation of the final $\mathrm{C}$ content per day. If that rate were to continue for 84 days (the development period) the slug could, theoretically, fix $0.91 \%$, or about $1 \%$ of its carbon.

Being able to fix $1 \%$ of one's carbon is not very photosynthetic one might say, but $1 \%$ is still a far too generous estimate, we need to correct for at least two more factors. First, the young adults are only about $500 \mu \mathrm{m}$ long with an area of $0.25 \mathrm{~mm}^{2}$ (Schmitt et al., 2014), or $0.3 \%$ the area of the fully-grown animal, which has a plastid-containing surface area of roughly $1 \mathrm{~cm}^{2}$ (Figure 1A). Over the 84-day development period, on average half the surface area of the adult is available for photosynthetic activity, so that perhaps $0.5 \%$ of the animal's $\mathrm{C}$ can be contributed by photosynthesis.

But a contribution of $0.5 \%$ total $\mathrm{C}$ from photosynthesis to slug body weight is still too generous, because there is also the issue of carbon turnover. That is, the animals respire some of the $\mathrm{C}$ that they assimilate, whether from heterotrophic feeding (which is already $>99 \%$ of total C, as we see from our calculation so far), or from the plastid contribution. The turnover time, or halflife, of $\mathrm{C}$ has not been measured so far in E. timida. There are, however, very good numbers available for $\mathrm{C}$ half-life in animals of many different sizes (van der Zanden et al., 2015), where it is seen that C-turnover times in animals scale tightly with body size. From the published curves of van der Zanden et al. (2015), we can estimate that in the case of invertebrates that weigh as much as E. timida, the C half-life should fall in the range of 12 days. That means that at constant weight, half of the carbon atoms present in the animal at time zero are still present after 12 days. But we do not have to worry too much about the carbon halflife, because the measured value of $540 \mathrm{ng} \mathrm{C}$ per animal per $12-\mathrm{h}$ day is net incorporation, it already takes respiration into account. In the $12 \mathrm{~h}$ of dark, there is still respiration, so that the value of $0.5 \%$ of the animal's $\mathrm{C}$ needs to be halved once more (continued respiration but no photosynthesis in the 12-h dark phase) and we arrive at an estimate that roughly $0.25 \%$ of the adult's C can be contributed by photosynthesis, based on the most recent experimentally measured ${ }^{14} \mathrm{CO}_{2}$-based $\mathrm{CO}_{2}$ incorporation rates for slugs available in the literature (Christa et al., 2014).

Thus, E. timida might be able to cover about $0.25 \%$ of its body weight increase during development from $\mathrm{CO}_{2}$ fixation in plastids. That explains why some plastid-harboring sacoglossan slugs have been observed to lose weight in the light at the same rate as in the dark or with chemically inhibited photosynthesis (Christa et al., 2014).

However, as in any field of active scientific inquiry, there are conflicting reports, of course. For example, Laetz et al. (2017) recently reported that starch provided by plastids increases in E. timida during starvation before it decreases, and that this impacts slug survival. Those are important observations, but quantitative estimates of $\mathrm{CO}_{2}$ fixation based on ${ }^{14} \mathrm{CO}_{2}$ incorporation were lacking. Earlier reports of carbon fixation by plastids in sacoglossans based on stable carbon isotope ratios $\left({ }^{13} \mathrm{C} /{ }^{12} \mathrm{C}\right)$ gave very high estimates of net photosynthetic contribution by slug-sequestered plastids (Raven et al., 2001), but quantitative estimates of $\mathrm{CO}_{2}$ fixation based on ${ }^{14} \mathrm{CO}_{2}$ incorporation were again lacking. Some of the earliest ${ }^{14} \mathrm{CO}_{2}$ incorporation measurements from the 1970s delivered fairly high values (Hinde and Smith, 1975), but were also marked by considerable variation from measurement to measurement and in at least one case more ${ }^{14} \mathrm{CO}_{2}$ incorporation measured in the dark than in the light.

When we embarked upon measuring ${ }^{14} \mathrm{CO}_{2}$ incorporation in slugs, we also noticed disconcerting variation across experiments and puzzlingly high dark ${ }^{14} \mathrm{CO}_{2}$ incorporation values (AGMT and WFM, unpublished observations). We subsequently found that prolonged (overnight) and very strong acid treatment $(1 \mathrm{M} \mathrm{HCl})$ was needed to gasify and purge unincorporated ${ }^{14} \mathrm{CO}_{2}$ from animal homogenates after incubation experiments. If photosynthesis is the reason that sacoglossan slugs keep plastids, then we should be able to quantify that contribution via ${ }^{14} \mathrm{CO}_{2}$ incorporation measurements in other species that, like E. timida, sequester plastids.

\section{LOOKING INTO THE LITERATURE: EXPECTATIONS AND EVIDENCE}

If we dig into the literature on the possible function of photosynthesis in plastids during starvation in Sacoglossa, it is apparent that only very few studies carried out ${ }^{14} \mathrm{CO}_{2}$ incorporation measurements that would allow one to directly determine $\mathrm{CO}_{2}$ incorporation (Table 1). Furthermore, many studies lacked the appropriate controls that would permit a clear causal connection between photosynthetic $\mathrm{CO}_{2}$ fixation and animal survival, for example testing the effect of chemical inhibition of photosynthesis. There is a crucial difference between (a) the inference that sequestered, morphologically intact, plastids are important for enduring starvation (for possibly unknown reasons), and (b) the inference that sequestered, morphologically intact, plastids are providing $\mathrm{CO}_{2}$ fixation at rates that would provide significant nutrition to the animals. No previous work, nor the present calculations at hand, call into question the view that sequestered plastids in long term retention Sacoglossa have some kind of biological significance. But we are also not aware of any previous work that experimentally justifies interpretations or claims that the quantity of fixed carbon provided by plastids is sufficient to support the idea of a "photoautotrophic animal," as pervades the literature on plastidsequestering Sacoglossa, not seldom in the title or abstract. Our present calculations serve to underscore the point that measured ${ }^{14} \mathrm{CO}_{2}$ fixation rates for plastids sequestered in the cytosol of an animal cell cannot support animal growth.

\section{CONCLUSION}

The purpose of this paper is to provide a reference to which one might turn in the event that the media or an interested high school class calls, wanting to know whether the engineering of photosynthetic farm animals "like the slugs" might be a worthwhile avenue of scientific pursuit. The answer we obtain is that by weight, about $0.3 \%$ of the slug might be able to 
TABLE 1 | Overview of relevant literature on Sacoglossa and experimental details.

\section{References}

Trench, 1969

Greene, 1970

Trench et al., 1970

Taylor, 1971

Greene and Muscatine, 1972

Hinde and Smith, 1972

Trench et al., 1973

Gallop, 1974

Hinde and Smith, 1974

Trench et al., 1974

Hinde and Smith, 1975

Kremer and Schmitz, 1976

McLean, 1976

Trench and Ohlhorst, 1976

Clark and Busacca, 1978

Gallop et al., 1980

Clark et al., 1981

Weaver and Clark, 1981

Marín and Ros, 1989

de Freese and Clark, 1991

Marín and Ros, 1992

Marín and Ros, 1993

Mujer et al., 1996

Green et al., 2000

Wägele and Johnsen, 2001

Cueto et al., 2005

Casalduero and Muniain, 2006

Curtis et al., 2006

Evertsen et al., 2007

Casalduero and Muniain, 2008

Rumpho et al., 2008

Evertsen and Johnsen, 2009

Händeler et al., 2009

Pierce et al., 2009

Jesus et al., 2010

Maeda et al., 2010

Schwartz et al., 2010

Pierce et al., 2011

Wägele et al., 2011

Devine et al., 2012

Pelletreau et al., 2012

Bhattacharya et al., 2013

Christa et al., 2013

de Vries et al., 2013

Klochkova et al., 2013

Baumgartner et al., 2014

Pelletreau et al., 2014

Schmitt et al., 2014

Serôdio et al., 2014

Baumgartner et al., 2015

Christa et al., 2015

\# spec. (1) \# indv. (2) wgt/len (3)

${ }^{14} \mathrm{CO}_{2}$ (4) Fv/Fm (5) dark ctrl. (6) DCMU (7) Chl. (8) Starved (9) $\mathrm{O}_{2}(10)$

8

6

11

39

68

27

24

220

25

10

184

5

17

357

186

20

16

45

80

41

400

179

\section{$+$}

$+$

$+$

$+$

$+$

$+$

$+$

$$
\begin{array}{r}
+ \\
+
\end{array}
$$$$
+
$$$$
+
$$
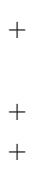

$+$

$+$$$
+
$$

$+$

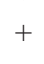

$+$

$+$

$+$

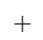

$+$

$+$

$+$

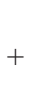

$+$

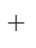

$+$

$+$

$+$

$+$
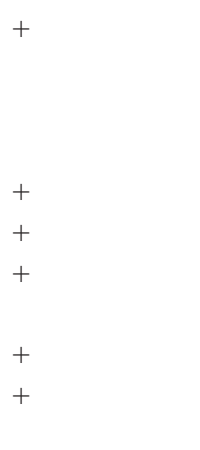

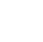

$+$
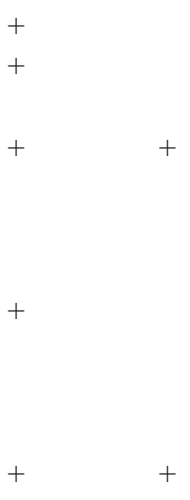

$+\quad+$

$+$

+
+
+
+

$+$

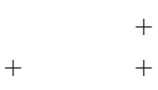

$+\quad+$

$+$

$+\quad+$

$+\quad+$

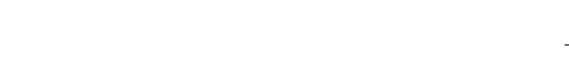

$+$

$+$

$+$

$+$

$+$

$2015-105$

(Continued) 
TABLE 1 | Continued

\begin{tabular}{|c|c|c|c|c|c|c|c|c|c|c|}
\hline References & \# spec. (1) & \# indv. (2) & wgt/len (3) & ${ }^{14} \mathrm{CO}_{2}$ (4) & Fv/Fm (5) & dark ctrl. (6) & DCMU (7) & Chl. (8) & Starved (9) & $\mathrm{O}_{2}(10)$ \\
\hline Cruz et al., 2015 & 2 & & & & + & + & & + & & \\
\hline Curtis et al., 2015 & 3 & & & & + & & & & + & \\
\hline de Vries et al., 2015 & 2 & & + & + & + & + & + & + & + & \\
\hline Martin et al., 2015 & 4 & & & & & & & + & & \\
\hline Laetz et al., 2017 & 1 & 40 & + & & + & & + & & + & \\
\hline Wade and Sherwood, 2017 & 1 & 69 & & & + & & & & + & \\
\hline
\end{tabular}

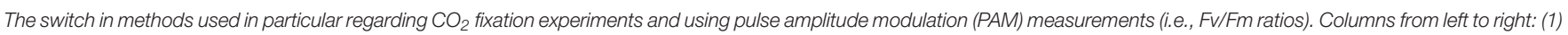

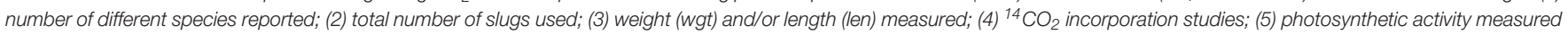

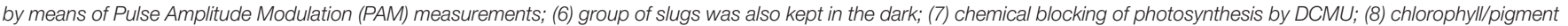
concentration measurements; (9) a group of slugs were starved throughout the experiments; (10) $\mathrm{O}_{2}$ evolution was measured.

survive from photosynthetic activity through its sequestered plastids. The other $99.7 \%$ has to live from normal ingested food, like the rest of us animals. Somewhat more bleak prospects arise for photosynthetic farm animals, because of their size and warm-blooded nature. In principle, the concept of photosynthetic animals is interesting. In practice, it underscores the observation that among all animals known so far; only seven species of sacoglossan slugs steal plastids from siphonaceous algae and sequester them long-term (de Vries et al., 2014b), apparently for reasons other than carbon fixation.

\section{AUTHOR CONTRIBUTIONS}

CR, SG, and WM drafted the MS. CR designed the figure and the table. CR, PJ, AT, SG, and WM all made a substantial, direct

\section{REFERENCES}

Bauchop, T., and Mountfort, D. O. (1981). Cellulose fermentation by a rumen anaerobic fungus in both the absence and the presence of rumen methanogens. Appl. Environ. Microbiol. 42, 1103-1110.

Baumgartner, F. A., Pavia, H., and Toth, G. B. (2014). Individual specialization to non-optimal hosts in a polyphagous marine invertebrate herbivore. PLOS ONE 9:e102752. doi: 10.1371/journal.pone.0102752

Baumgartner, F. A., Pavia, H., and Toth, G. B. (2015). Acquired phototrophy through retention of functional chloroplasts increases growth efficiency of the sea slug Elysia viridis. PLoS ONE 10:e120874. doi: 10.1371/journal.pone.0120874

Bhattacharya, D., Pelletreau, K. N., Price, D. C., Sarver, K. E., and Rumpho, M. E. (2013). Genome analysis of Elysia chlorotica egg DNA provides no evidence for horizontal gene transfer into the germ line of this kleptoplastic mollusc. Mol. Biol. Evol. 30, 1843-1852. doi: 10.1093/molbev/mst084

Bouton, P. E., Ford, A. L., Harris, P. V., Shorthose, W. R., Ratcliff, D., and Morgan, J. H. (1978). Influence of animal age on the tenderness of beef: muscle differences. Meat Sci. 2, 301-311. doi: 10.1016/0309-1740(78)90031-1

Brody, S., and Ragsdale, A. C. (1930). The rate of growth of the dairy cow V. Extra uterine growth in linear dimensions. J. Gen. Physiol. 52, 1220-1232.

Casalduero, F. G., and Muniain, C. (2006). Photosynthetic activity of the solar-powered lagoon mollusc Elysia timida (Risso, 1818) (Opisthobranchia: Sacoglossa). Symbiosis 41, 151-158.

Casalduero, F. G., and Muniain, C. (2008). The role of kleptoplasts in the survival rates of Elysia timida (Risso, 1818): (Sacoglossa: Opisthobranchia) during periods of food shortage. J. Exp. Mar. Biol. Ecol. 357, 181-187. doi: 10.1016/j.jembe.2008.01.020 and intellectual contribution to the work, and approved it for publication.

\section{FUNDING}

We thank the DFG GO1825/4-1 and GO665/9-1 (SG and PJ) the NWO (AT), and the ERC 666053 (WM) for financial support.

\section{ACKNOWLEDGMENTS}

We thank Steffen Köhler (CAi, HHU) for help with slug and algae photography and we thank Mimi Maurer and her biology classmates at the Hohenstaufen-Gymnasium in Göppingen (Baden-Württemberg, Germany) for prompting us to perform a few calculations about the bounds on possible quantitative contribution of plastids in animal cells to photosynthesis.

Christa, G., Händeler, K., Kück, P., Vleugels, M., Franken, J., Karmeinski, D., et al. (2015). Phylogenetic evidence for multiple independent origins of functional kleptoplasty in Sacoglossa (Heterobranchia, Gastropoda). Organ. Divers. Evol. 15, 23-36. doi: 10.1007/s13127-014-0189-z

Christa, G., Wescott, L., Schäberle, T. F., König, G. M., and Wägele, H. (2013). What remains after 2 months of starvation? Analysis of sequestered algae in a photosynthetic slug, Plakobranchus ocellatus (Sacoglossa, Opisthobranchia), by barcoding. Planta 237, 559-572. doi: 10.1007/s00425-012-1788-6

Christa, G., Zimorski, V., Woehle, C., Tielens, A. G. M., Wägele, H., Martin, W. F., et al. (2014). Plastid-bearing sea slugs fix $\mathrm{CO}_{2}$ in the light but do not require photosynthesis to survive. Proc. R. Soc. Lond. Biol. Sci. 281:20132493. doi: $10.1098 /$ rspb.2013.2493

Clark, K. B., and Busacca, M. (1978). Feeding specificity and chloroplast retention in four tropical Ascoglossa, with a discussion of the extent of chloroplast symbiosis and the evolution of the order. J. Moll. Stud. 44, 272-282.

Clark, K. B., Jensen, K. R., Stirts, H. M., and Fermin, C. (1981). Chloroplast symbiosis in a non-Elysiid mollusc, Costasiella lilianae Marcus (Hermaeidae: Ascoglossa (= Sacoglossa): effects of temperature, light intensity, and starvation on carbon fixation rate). Biol. Bull. 160, 43-54. doi: 10.2307/1540899

Cruz, S., Cartaxana, P., Newcomer, R., Dionísio, G., Calado, R., Serôdio, J., et al. (2015). Photoprotection in sequestered plastids of sea slugs and respective algal sources. Sci. Rep. 5:7904. doi: 10.1038/srep07904

Cueto, M., D’Croz, L., Maté, J. L., San-Martín, A., and Darias, J. (2005). Elysiapyrones from Elysia diomedea. Do such metabolites evidence an enzymatically assisted electrocyclization cascade for the biosynthesis of their bicyclo[4.2. 0] octane Core? Org. Lett. 7, 415-418. doi: 10.1021/ol0477428

Curtis, N. E., Massey, S. E., and Pierce, S. K. (2006). The symbiotic chloroplasts in the sacoglossan Elysia clarki are from several algal 
species. Invertebrate Biol. 125, 336-345. doi: 10.1111/j.1744-7410.2006. 00065.x

Curtis, N. E., Middlebrooks, M. L., Schwartz, J. A., and Pierce, S. K. (2015). Kleptoplastic sacoglossan species have very different capacities for plastid maintenance despite utilizing the same algal donors. Symbiosis 65, 23-31. doi: 10.1007/s13199-015-0317-3

de Freese, D. E., and Clark, K. B. (1991). Transepidermal uptake of dissolved free amino acids from seawater by three ascoglossan opisthobranchs. J. Mollus. Stud. 57, 65-74. doi: 10.1093/mollus/57.Supplement_Part_4.65

de Vries, J., Christa, G., and Gould, S. B. (2014a). Plastid survival in the cytosol of animal cells. Trends Plant Sci. 19, 347-350. doi: 10.1016/j.tplants.2014.03.010

de Vries, J., Habicht, J., Woehle, C., Huang, C., Christa, G., Wägele, H., et al. (2013). Is $\mathrm{ftsH}$ the key to plastid longevity in sacoglossan slugs? Genome Biol. Evol. 5, 2540-2548. doi: 10.1093/gbe/evt205

de Vries, J., Rauch, C., Christa, G., and Gould, S. B. (2014b). A sea slug's guide to plastid symbiosis. Acta Soc. Bot. Pol. 83, 415-421. doi: 10.5586/asbp. 2014.042

de Vries, J., Woehle, C., Christa, G., Wagele, H., Tielens, A. G., Jahns, P., et al. (2015). Comparison of sister species identifies factors underpinning plastid compatibility in green sea slugs. Proc. R. Soc. Lond. Biol. Sci. 282:20142519. doi: $10.1098 / \mathrm{rspb} .2014 .2519$

Devine, S. P., Pelletreau, K. N., and Rumpho, M. E. (2012). 16S rDNA-based metagenomic analysis of bacterial diversity associated with two populations of the kleptoplastic sea slug Elysia chlorotica and its algal prey Vaucheria litorea. Biol. Bull. 223, 138-154. doi: 10.1086/BBLv223n1p138

Dijkstra, J., Boer, H., van Bruchem, J., Bruining, M., and Tamminga, S. (1993). Absorption of volatile fatty acids from the rumen of lactating dairy cows as influenced by volatile fatty acid concentration, $\mathrm{pH}$, and rumen liquid volume. Br. J. Nutr. 69, 385-396. doi: 10.1079/BJN19930041

Evertsen, J., and Johnsen, G. (2009). In vivo and in vitro differences in chloroplast functionality in the two north Atlantic sacoglossans (Gastropoda, Opisthobranchia) Placida dendritica and Elysia viridis. Mar. Biol. 156, 847-859. doi: 10.1007/s00227-009-1128-y

Evertsen, J., Burghardt, I., Johnsen, G., and Wägele, H. (2007). Retention of functional chloroplasts in some sacoglossans from the Indo-Pacific and Mediterranean. Mar. Biol. 151, 2159-2166. doi: 10.1007/s00227-007-0648-6

Gallop, A. (1974). Evidence for the presence of a "factor" in Elysia viridis which stimulates photosynthate release from its symbiotic chloroplasts. New Phytol. 73, 1111-1117. doi: 10.1111/j.1469-8137.1974.tb02140.x

Gallop, A., Bartrop, J., and Smith, D. C. (1980). The biology of chloroplast acquisition by Elysia viridis. Proc. R. Soc. Lond. B Biol. Sci. 207, 335-349. doi: $10.1098 / \mathrm{rspb} .1980 .0027$

Giles, K. L., and Sarafis, V. (1972). Chloroplast survival and division in vitro. Nature 236, 56-58. doi: 10.1038/newbio236056a0

Green, B. J., Li, W. Y., Manhart, J. R., Fox, T. C., Summer, E. J., Kennedy, R. A., et al. (2000). Mollusc-algal chloroplast endosymbiosis. Photosynthesis, thylakoid protein maintenance, and chloroplast gene expression continue for many months in the absence of the algal nucleus. Plant Physiol. 124, 331-342. doi: $10.1104 /$ pp.124.1.331

Greene, R. W. (1970). Symbiosis in sacoglossan opisthobranchs: functional capacity of symbiotic chloroplasts. Mar. Biol. 7, 138-142. doi: 10.1007/BF00354917

Greene, R. W., and Muscatine, L. (1972). Symbiosis in sacoglossan opisthobranchs: photosynthetic products of animal-chloroplast associations. Mar. Biol. 14, 253-259.

Haldane, J. B. S. (1926). On Being the Right Size. Harper's Magazine. 424-427.

Händeler, K., Grzymbowski, Y. P., Krug, P. J., and Wägele, H. (2009). Functional chloroplasts in metazoan cells - a unique evolutionary strategy in animal life. Front. Zool. 6:28. doi: 10.1186/1742-9994-6-28

Heldal, M., Norland, S., and Tumyr, O. (1985). X-ray microanalytic method for measurement of dry matter and elemental content of individual bacteria. Appl. Environ. Microbiol. 50, 1251-1257.

Hinde, R., and Smith, D. C. (1972). Persistence of functional chloroplasts in Elysia viridis (Opisthobranchia, Sacoglossa). Nature 239, 30-31. doi: $10.1038 /$ newbio239030a0

Hinde, R., and Smith, D. C. (1974). "Chloroplast symbiosis" and the extent to which it occurs in Sacoglossa (Gastropoda: Mollusca). Biol. J. Linn. Soc. 6, 349-356. doi: 10.1111/j.1095-8312.1974.tb00729.x
Hinde, R., and Smith, D. C. (1975). The role of photosynthesis in the nutrition of the mollusc Elysia viridis. Biol. J. Linn. Soc. 7, 161-171. doi: 10.1111/j.1095-8312.1975.tb00738.x

Jensen, K. R. (2007). Biogeography of the Sacoglossa (Mollusca, Opisthobranchia). Bonner Zool. Beiträge 55, 255-281.

Jesus, B., Ventura, P., and Calado, G. (2010). Behaviour and a functional xanthophyll cycle enhance photo-regulation mechanisms in the solar-powered sea slug Elysia timida (Risso, 1818). J. Exp. Mar. Biol. Ecol. 395, 98-105. doi: 10.1016/j.jembe.2010.08.021

Klochkova, T. A., Han, J. W., Chah, K. H., Kim, R. W., Kim, J. H., Kim, K. Y., et al. (2013). Morphology, molecular phylogeny and photosynthetic activity of the sacoglossan mollusc, Elysia nigrocapitata, from Korea. Mar. Biol. 160, 155-168. doi: 10.1007/s00227-012-2074-7

Kremer, B. P., and Schmitz, K. (1976). Aspects of 14CO2-fixation by endosymbiotic rhodoplasts in the marine opisthobranchiate Hermaea bifida. Mar. Biol. 34, 313-316. doi: 10.1007/BF00398124

Laetz, E. M. J., Moris, V. C., Moritz, L., Haubrich, A. N., and Wägele, H. (2017). Photosynthate accumulation in solar powered sea slugs starving slugs survive due to accumulated starch reserves. Front. Zool. 14:4. doi: 10.1186/s12983-016-0186-5

Maeda, T., Kajita, T., Maruyama, T., and Hirano, Y. (2010). Molecular phylogeny of the Sacoglossa, with a discussion of gain and loss of kleptoplasty in the evolution of the group. Biol. Bull. 219, 17-26. doi: 10.1086/BBLv219n1p17

Marín, A., and Ros, J. (1989). The chloroplast-animal association in four Iberian sacoglossan opisthobranchs: Elysia timida, Elysia translucens, Thuridilla hopei and Bosellia mimetica. Sci. Mar. 53, 429-440.

Marín, A., and Ros, J. (1993). Ultrastructural and ecological aspects of the development of chloroplast retention in the sacoglossan gastropod Elysia timida. J. Mollus Stud. 59, 95-104. doi: 10.1093/mollus/59.1.95

Marín, A., and Ros, J. D. (1992). Dynamics of a peculiar plant-herbivore relationship: the photosynthetic ascoglossan Elysia timida and the chlorophycean Acetabularia acetabulum. Mar. Biol. 112, 677-682. doi: $10.1007 / \mathrm{BF} 00346186$

Martin, R., Walther, P., and Tomaschko, K. H. (2015). Variable retention of kleptoplast membranes in cells of sacoglossan sea slugs: plastids with extended, shortened and non-retained durations. Zoomorphology 134, 523-529. doi: 10.1007/s00435-015-0278-3

McLean, N. (1976). Phagocytosis of chloroplasts in Placida dendritica (Gastropoda: Sacoglossa). J. Exp. Zool. A Ecol. Genet. Physiol. 197, 321-329.

Mujer, C. V., Andrews, D. L., Manhart, J. R., Pierce, S. K., and Rumpho, M. E. (1996). Chloroplast genes are expressed during intracellular symbiotic association of Vaucheria litorea plastids with the sea slug Elysia chlorotica. Proc. Natl. Acad. Sci. U.S.A. 93, 12333-12338. doi: 10.1073/pnas.93.22. 12333

Pelletreau, K. N., Weber, A. P., Weber, K. L., and Rumpho, M. E. (2014). Lipid accumulation during the establishment of kleptoplasty in Elysia chlorotica. PLoS ONE 9:e97477. doi: 10.1371/journal.pone.0097477

Pelletreau, K. N., Worful, J. M., Sarver, K. E., and Rumpho, M. E. (2012). Laboratory culturing of Elysia chlorotica reveals a shift from transient to permanent kleptoplasty. Symbiosis 58, 221-232. doi: 10.1007/s13199-012-0192-0

Pierce, S. K., Curtis, N. E., and Schwartz, J. A. (2009). Chlorophyll a synthesis by an animal using transferred algal nuclear genes. Symbiosis 49, 121-131. doi: 10.1007/s13199-009-0044-8

Pierce, S. K., Fang, X., Schwartz, J. A., Jiang, X., Zhao, W., Curtis, N. E., et al. (2011). Transcriptomic evidence for the expression of horizontally transferred algal nuclear genes in the photosynthetic sea slug, Elysia chlorotica. Mol. Biol. Evol. 29, 1545-1556. doi: 10.1093/molbev/msr316

Pierce, S., Biron, R., and Rumpho, M. E. (1996). Endosymbiotic chloroplasts in molluscan cells contain proteins synthesized after plastid capture. J. Exp. Biol. 199, 2323-2330.

Raven, J. A., Walker, D. I., Jensen, K. R., Handley, L. L., Scrimgeour, C. M., and McInroy, S. G. (2001). What fraction of the organic carbon in sacoglossans is obtained from photosynthesis by kleptoplastids? An investigation using the natural abundance of stable carbon isotopes. Mar. Biol. 138, 537-545. doi: $10.1007 / \mathrm{s} 002270000488$

Rumpho, M. E., Summer, E. J., Green, B. J., Fox, T. C., and Manhart, J. R. (2001). Mollusc/algal chloroplast symbiosis: how can isolated chloroplasts continue 
to function for months in the cytosol of a sea slug in the absence of an algal nucleus? Zoology 104, 303-312. doi: 10.1078/0944-2006-00036

Rumpho, M. E., Worful, J. M., Lee, J., Kannan, K., Tyler, M. S., Bhattacharya, et al. (2008). Horizontal gene transfer of the algal nuclear gene psbO to the photosynthetic sea slug Elysia chlorotica. Proc. Natl. Acad. Sci. U.S.A. 105, 17867-17871. doi: 10.1073/pnas.0804968105

Schmitt, V., Händeler, K., Gunkel, S., Escande, M. L., Menzel, D., Gould, S. B., et al. (2014). Chloroplast incorporation and long-term photosynthetic performance through the life cycle in laboratory cultures of Elysia timida (Sacoglossa, Heterobranchia). Front. Zool. 11:5. doi: 10.1186/1742-9994-11-5

Schwartz, J. A., Curtis, N. E., and Pierce, S. K. (2010). Using algal transcriptome sequences to identify transferred genes in the sea slug, Elysia chlorotica. Evol. Biol. 37, 29-37. doi: 10.1007/s11692-010-9079-2

Serôdio, J., Cruz, S., Cartaxana, P., and Calado, R. (2014). Photophysiology of kleptoplasts: photosynthetic use of light by chloroplasts living in animal cells. Philos. Trans. R. Soc. B Biol. Sci. 369:20130242. doi: 10.1098/rstb.2013.0242

Smith, D. C., and Bernays, E. A. (1991). Why do so few animals form endosymbiotic associations with photosynthetic microbes? Philos. Trans. $R$. Soc. B Biol. Sci. 333, 225-230. doi: 10.1098/rstb.1991.0071

Taylor, D. L. (1971). Photosynthesis of symbiotic chloroplasts in Tridachia crispata (Bergh). Comp. Biochem. Physiol. 38, 233-236. doi: 10.1016/0300-9629(71)90111-3

Tilman, D., Cassman, K. G., Matson, P. A., Naylor, R., and Polasky, S. (2012). Agricultural sustainability and intensive production practices. Nature 418, 671-677. doi: 10.1038/nature01014

Tollenaar, M. (1983). Potential vegetative productivity in Canada. Can. J. Plant Sci. 63, 1-10. doi: 10.4141/cjps83-001

Trench, M. E., Trench, R. K., and Muscatine, L. (1970). Utilization of photosynthetic products of symbiotic chloroplasts in mucus synthesis by Placobranchus ianthobapsus (Gould), Opisthobranchia, Sacoglossa. Comp. Biochem. Physiol. 37, 113-117. doi: 10.1016/0010-406X(70)90964-3

Trench, R. K. (1969). Chloroplasts as functional endosymbionts in the mollusc Tridachia crispate (Bergh), (Opisthobranchia, Sacoglossa). Nature 222, 1071-1072. doi: 10.1038/2221071a0

Trench, R. K., and Ohlhorst, S. (1976). The stability of chloroplasts from siphonaceous algae in symbiosis with sacoglossan molluscs. New Phytol. 76, 99-109. doi: 10.1111/j.1469-8137.1976.tb01442.x

Trench, R. K., Boyle, J. E., and Smith, D. C. (1973). The association between chloroplasts of Codium fragile and the mollusc Elysia viridis. II. Chloroplast ultrastructure and photosynthetic carbon fixation in E. viridis. Proc. R. Soc. Lond. B Biol. Sci. 184, 63-81. doi: 10.1098/rspb.1973.0031

Trench, R. K., Boyle, J. E., and Smith, D. C. (1974). The association between chloroplasts of Codium fragile and the mollusc Elysia viridis. III. Movement of photosynthetically fixed ${ }^{14} \mathrm{C}$ in tissues of intact living, E. viridis and in Tridachia crispata. Proc. R. Soc. Lond. B Biol. Sci. 185, 453-464. doi: 10.1098/rspb.1974.0029

van der Zanden, M. J., Clayton, M. K., Moody, E. K., Solomon, C. T., and Weidel, B. C. (2015). Stable isotope turnover and half-life in animal tissues: a literature synthesis. PLoS ONE 10:e0116182. doi: 10.1371/journal.pone.0116182

Wade, R. M., and Sherwood, A. R. (2017). Molecular determination of kleptoplast origins from the sea slug Plakobranchus ocellatus (Sacoglossa, Gastropoda) reveals cryptic bryopsidalean (Chlorophyta) diversity in the Hawaiian Islands. J. Phycol. 53, 467-475. doi: 10.1111/jpy.12503

Wägele, H., Deusch, O., Händeler, K., Martin, R., Schmitt, V., Christa, G., et al. (2011). Transcriptomic evidence that longevity of acquired plastids in the photosynthetic slugs Elysia timida and Plakobranchus ocellatus does not entail lateral transfer of algal nuclear genes. Mol. Biol. Evol. 28, 699-706. doi: $10.1093 / \mathrm{molbev} / \mathrm{msq} 239$

Wägele, M., and Johnsen, G. (2001). Observations on the histology and photosynthetic performance of "solar-powered" opisthobranchs (Mollusca, Gastropoda, Opisthobranchia) containing symbiotic chloroplasts or zooxanthellae. Organ. Divers. Evol. 1, 193-210. doi: 10.1078/1439-609200016

Watson, D. J. (1947). Comparative physiological studies on the growth of field crops: I. Variation in net assimilation rate and leaf area. Ann. Appl. Biol. 11, 41-76. doi: 10.1093/oxfordjournals.aob.a083148

Weaver, S., and Clark, K. B. (1981). Light intensity and color preferences of five ascoglossan (= sacoglossan) molluscs (Gastropoda: Opisthobranchia) a comparison of chloroplast-symbiotic and aposymbiotic species. Mar. Freshw. Behav. Phys. 7, 297-306. doi: 10.1080/102362481093 86991

Wilhelm, W. W., Ruwe, K., and Schlemmer, M. R. (2000). Comparison of three leaf area index meters in a corn canopy. Crop Sci. 40, 1179-1183. doi: $10.2135 /$ cropsci2000.4041179x

Conflict of Interest Statement: The authors declare that the research was conducted in the absence of any commercial or financial relationships that could be construed as a potential conflict of interest.

The reviewer BML and handling Editor declared their shared affiliation, and the handling Editor states that the process met the standards of a fair and objective review.

Copyright (C) 2017 Rauch, Jahns, Tielens, Gould and Martin. This is an open-access article distributed under the terms of the Creative Commons Attribution License (CC $B Y)$. The use, distribution or reproduction in other forums is permitted, provided the original author(s) or licensor are credited and that the original publication in this journal is cited, in accordance with accepted academic practice. No use, distribution or reproduction is permitted which does not comply with these terms. 